\title{
Hit identification of FGFR1 inhibitors using receptor-based virtual screening
}

\author{
S. S. Tarnavskiy, M. V. Protopopov, O. V. Borovykov, A. O. Prykhod'ko, \\ V. G. Bdzhola, S. M. Yarmoluk, V. I. Matyushok, A. O. Balanda \\ Institute of Molecular Biology and Genetics, NAS of Ukraine \\ 150, Akademika Zabolotnoho Str., Kyiv, Ukraine, 03143
}

\begin{abstract}
Aim. To identify novel FGFR1 inhibitors using the virtual screening approach. Methods. Virtual screening of a small organic compounds library was performed by molecular docking using the Autodock 4.2.6 program package. The compounds activity was determined by in vitro biochemical tests using $\gamma$-32P ATP. Results. In vitro experiments demonstrated that 18 compounds belonging to three chemical classes had an inhibitory activity against FGFR1 with IC50 values in the range from 1.8 to $71 \mu \mathrm{M}$. Conclusions. Several FGFR1 inhibitors were found using molecular modeling and biochemical testing. These compounds are excellent candidates for further chemical optimization.
\end{abstract}

Ke yword s: Fibroblast growth factor receptor 1, molecular docking, virtual screening, in vitro testing.

\section{Introduction}

Fibroblast growth factor receptor 1 (FGFR1) is a receptor tyrosine kinase which is involved in the regulation of cell growth, cell proliferation, cell differentiation, embryonic development, angiogenesis and other important physiological functions. The dysfunction of FGFR1 is associated with many disorders including cancer [1]. In particular, FGFR1 normally mutated in several of the deadliest human cancers, including lung cancer, breast cancer, glioblastoma, prostate cancer, ovarian cancer and liver cancer [2-7]. Hence, FGFR1 is considered as an at- tractive target for the development of therapeutic inhibitors of tumor growth and metastasis.

The aim of this work was to search for new FGFR1 inhibitors applying virtual screening of the collection of the Department of Medicinal Chemistry comprising more than 150,000 compounds. Earlier, using molecular docking of this collection we identified several classes of FGFR1 inhibitors, such as N-phenylnaphthostyril-1-sulfonamides [8], $\mathrm{N}$-phenylthieno[2,3-d]pyrimidin-4-amines [9], quinazolines [10], oxindoles [11], (1H-benzoimidazol-2-yl)-phenyl-1,2-dihydropyrrol-3-ones [12] and flavones [13].

(C) 2019 S. S. Tarnavskiy et al.; Published by the Institute of Molecular Biology and Genetics, NAS of Ukraine on behalf of Biopolymers and Cell. This is an Open Access article distributed under the terms of the Creative Commons Attribution License (http://creativecommons.org/licenses/by/4.0/), which permits unrestricted reuse, distribution, and reproduction in any medium, provided the original work is properly cited 


\section{Materials and Methods}

Preparation of reagents and solvents. Initial reagents were purchased from commercial suppliers of Acros and Fluka and were used without further purification. Solvents were prepared according to standard techniques.

Investigation of physicochemical and spectral properties of substances. The melting points were measured on a Kofler device. The NMR spectra of ${ }^{1} \mathrm{H}$ and ${ }^{13} \mathrm{C}$ NMR were measured on a Varian VXR 400 spectrometer at 400 and $100 \mathrm{MHz}$, respectively. The internal standard is TMS. HPLC-MS analysis was performed using Agilent 1100 LC / MSD SL splitter module and Mass Quad G1956B proton ionization mass detector. HPLC was performed using Zorbax SB-C18, Rapid Resolution HT Cartridge $4.6 \times 30 \mathrm{~mm}$ 1.8-Micron. The compounds were detected at $\lambda=215 \mathrm{~nm}$ using a Diode Array G1315B detector.

\section{Molecular docking}

Preparation of ligand and receptor molecules. The Autodock 4.2.6 programs package was used for the receptor-based flexible docking [14]. Ligands were prepared by Vega ZZ (command line) [15] and MGL Tools 1.5.6 [14]. The incoming formats of receptor and ligands data were converted into the PDBQTformat with Vega ZZ in AUTODOCK force field. This format contains the coordinates of the atoms and partial charges. Hydrogen atoms were removed from nonpolar atoms. The receptor was prepared using MGL Tools and AutoGrid [14].

We used the docking parameters reported earlier [16].

Flexible docking. The catalytic subunit of protein kinase FGFR1 complex with inhibitor
(PDB code 5O49) was used for molecular docking [17]. Water molecules, ions, and ligands were removed from the PDB file.

\section{Visual analysis}

A visual analysis of the results of molecular docking (interaction of compounds with the amino acid residues of FGFR1 ATP-binding site) was carried out in the Discovery Studio Visualizer 4.0 (http://accelrys.com/).

\section{In vitro testing}

The FGFR1 kinase assays with recombinant cytoplasmic domain of the FGFR1 tyrosine kinase (Millipore, Cat. N. 14-582) were performed in the solution of total volume of $30 \mu$ containing $10 \mathrm{mM}$ MOPS ( $\mathrm{pH} 7.2$ ), $0.1 \mathrm{mM}$ sodium orthovanadate, $0.2 \mathrm{mM}$ EDTA, $0.002 \%$ Brij 35 , $0.2 \mathrm{mg} / \mathrm{ml} \mathrm{BSA}, 0.02 \% \beta$-mercaptoethanol, 250 $\mu \mathrm{M}$ peptide substrate (KKKSPGEYVNIEFG, GenScript), various concentrations of inhibitor dissolved in DMSO (final DMSO concentration in probe less than $1 \%$ ) and $10 \mathrm{mU}$ of enzyme. The reaction was initiated by the addition of ATP (50 $\mu \mathrm{M}$ ATP, $25 \mathrm{mM} \mathrm{MgAc}$ containing $0.1 \mu \mathrm{Ci}$ of $\left[\gamma_{-}{ }^{32} \mathrm{P}\right]$ ATP per probe) and samples incubated at $30^{\circ} \mathrm{C}$ for $25 \mathrm{~min}$. The reaction was terminated by the addition of $5 \%$ phosphoric acid and the precipitation of material onto phosphocellulose filters "Whatman P81". Filters were washed three times with $0.75 \%$ phosphoric acid and the incorporation of $\left[{ }^{32} \mathrm{P}\right]$ into the peptide substrate was determined by counting the radioactivity retained on the filters in a PerkinElmer scintillation counter. Kinase residual activity was expressed in percentages with respect to DMSO control. The concentration of compound that inhibited enzymatic activity by $50 \%$ (IC50) was determined graphically. 


\section{Chemical synthesis}

The chemical synthesis of benzaldehyde derivatives of 1,3-thiazol-2-yl hydrazones was performed according to the standard procedure [18]. Compounds 1, 2, 3, 4 and 5 were prepared by reaction of the thiosemicarbazone of the corresponding benzaldehyde A with the corresponding 2-chloro-acetophenone B boiling in butanol with 1 equivalent of ammonia after the reaction and at yields of 55-78\% (scheme 1).

Synthesis of derivatives of 1-phenyl-3-phenylamino-4-(phenyl)thio-1H-pyrrole-2,5-dione was performed according to our methods [23, 24]. Compound 9 was prepared by reacting 3,4-dichloro-1H-pyrrole-2,5-diones with the corresponding aniline in $79 \%$ yield. For com- pounds 7 and 8, we developed efficient fastgrowing synthesis (without the separation of the intermediate product). Namely, in dioxane solution, a mixture of one equivalent of the corresponding 3,4-dichloro-1H-pyrrole-2,5diones with two equivalents of aniline was added. To this solution, after 1.1 hour, $1.1 \mathrm{eq}$ of the corresponding thiophenol and 1.1 equivalents of triethylamine were added and continued to boil for another 1 hour. The precipitate of the final product dropped out from the cooled solution was filtered off, washed twice with isopropanol and dried. Yields of compounds 7 and 8 were $49 \%$ and $46 \%$ respectively (Scheme 2).

In the process of one-stage synthesis according to Scheme 2, in one case two times
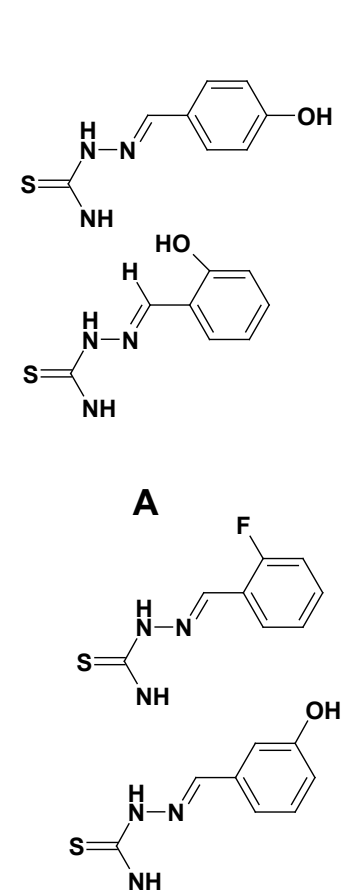
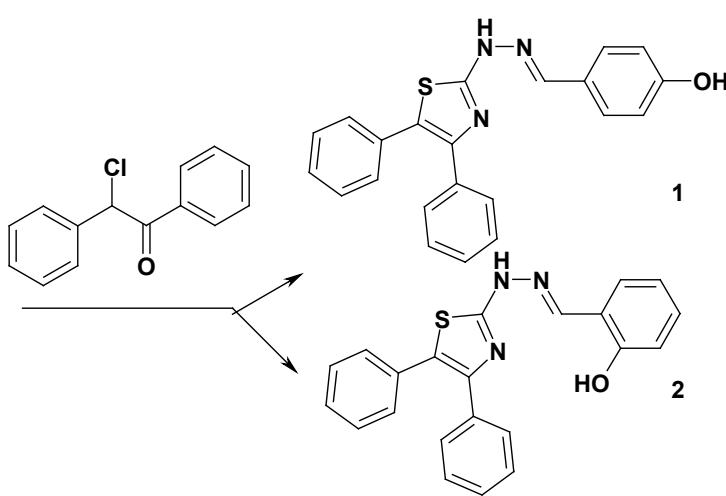

B

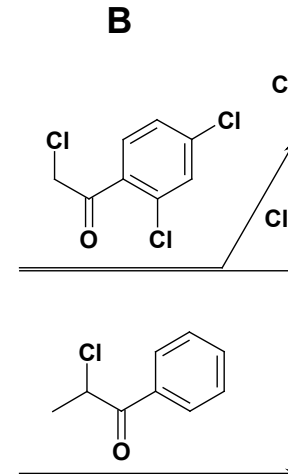

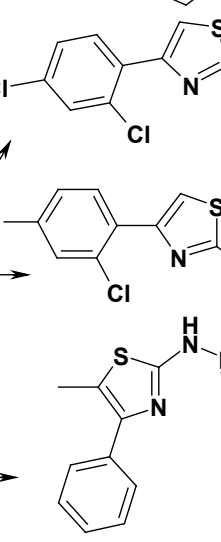

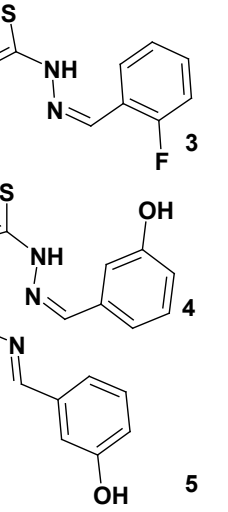

Scheme 1. Synthesis of derivatives of benzaldehyde 1,3-thiazol-2-yl hydrazones 


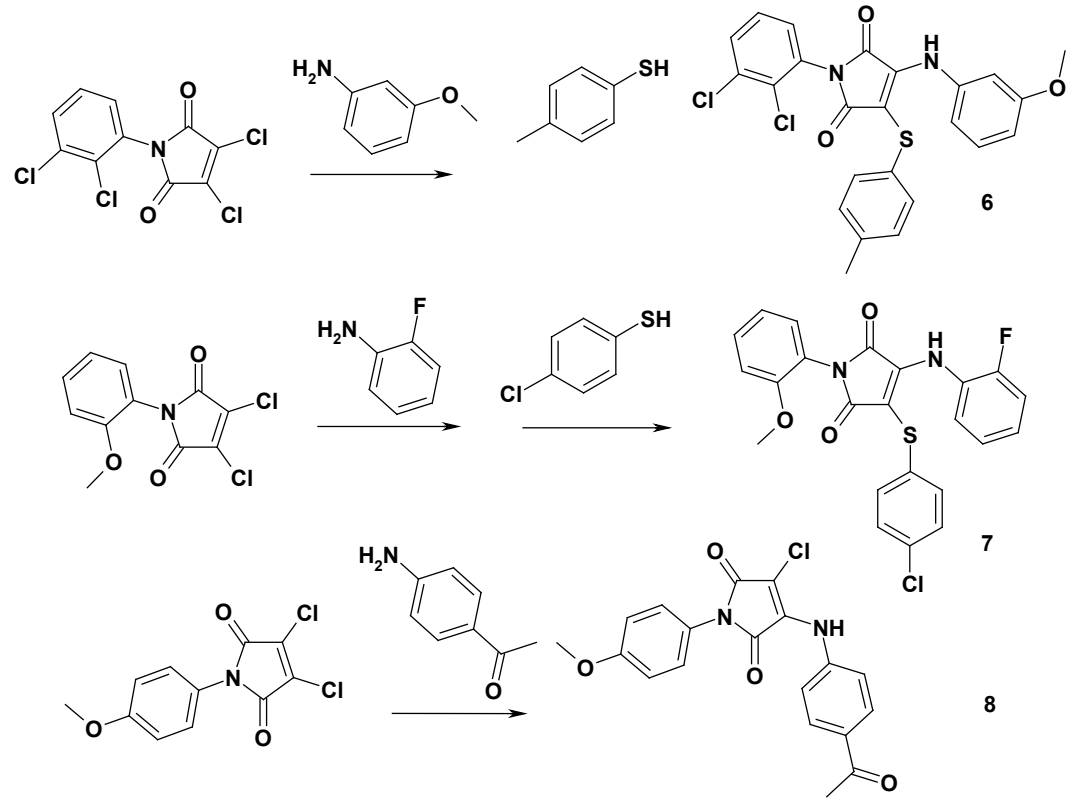

Scheme 2. Synthesis of derivatives of 1-phenyl-3-phenylamino4-(phenyl)thio-1H-pyrrole-2,5-dione and 3-[(4-acetylphenyl)amino]4-chloro-1-(4-methoxyphenyl)-1Hpyrrole-2,5-dione more thiophenol and triethylamine were added, i.e. 2.2 equals each. Interestingly, 3 - [(4-chlorophenyl) amino]-1-phenyl-1H-pyrrole-2,5dione (Compound 9, yield: $46 \%$ ) was obtained. As a result of studying the reaction products, diphenyl disulfide was also identified (Scheme 3). In our opinion (hypothesis), intermediate compound $\mathrm{S}$ is first formed, which under the action of triethylamine, by elimination of diphenyldisulfide, is converted into compound 9.

Synthesis of 4,6-substituted derivatives of 3-amino-thieno[2,3-b] pyridine-2-carboxamides was performed according to standard procedures [19, 20, 21, 22]. Compounds 10-18 were prepared (Scheme 4 ) by the reaction of 4,6-derivatives of 2-mercapto-3-cyano-pyridine with the corresponding chloroacetamides in alkaline conditions. (Yield: 58-72\%).

\section{Results and Discussion}

150,000 organic compounds of our combinatorial library were docked into ATP-binding site of FGFR1. The best scored compounds were selected for biochemical tests using the in vitro FGFR1 kinase assays.

According to the results of in vitro tests 18 compounds showed the inhibitory activity to-

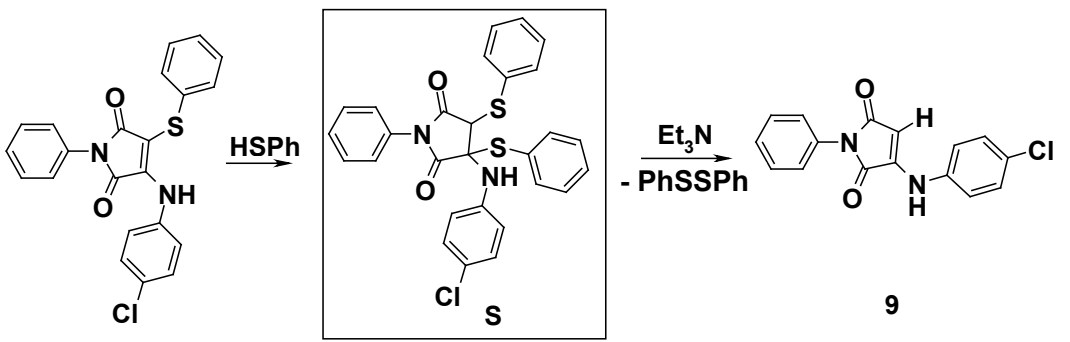

Scheme 3. Features of the synthesis of compound 5 and possible intermediate. 


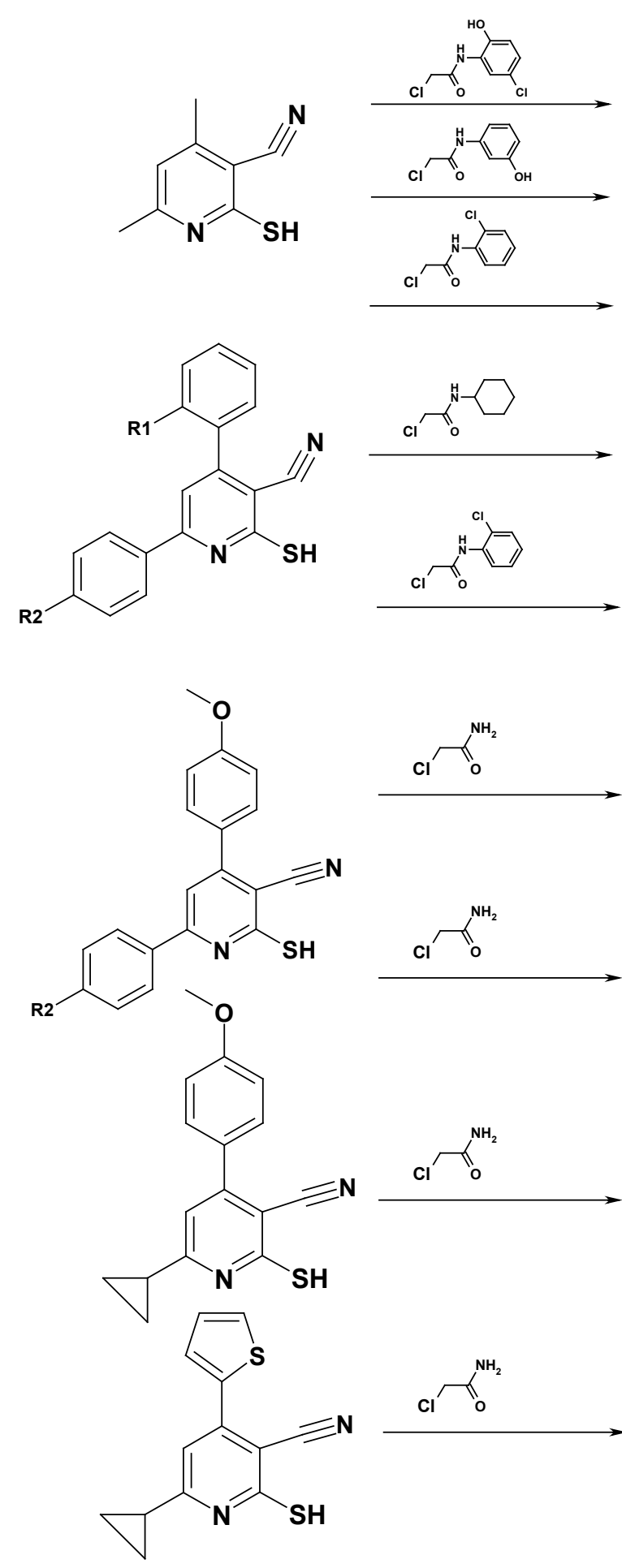

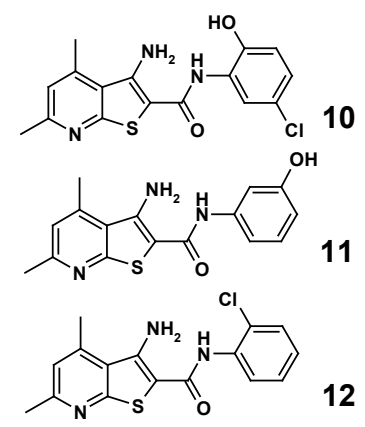

Scheme 4. 4,6-substituted derivatives of 3-aminothieno[2,3-b]pyridine2-carboxamides.
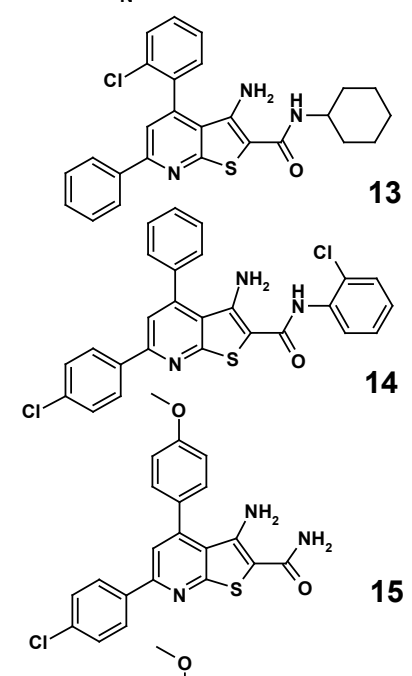

15
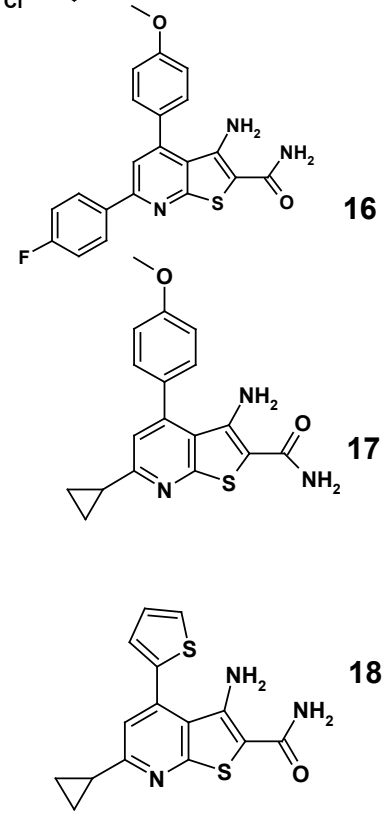
wards FGFR1 with $\mathrm{IC}_{50}$ values in the range from 1.8 to $71 \mu \mathrm{M}$. The structures and $\mathrm{IC}_{50}$ values of the tested compounds are shown in Table 1.

18 compounds belong to 3 chemical classes of inhibitors: 1,3-thiazol-2-yl hydrazones, 1-phenyl-3-phenylamino-4-(phenyl)thio-1Hpyrrole-2,5-diones and 4,6-substituted derivatives of 3-amino-thieno[2,3-b]pyridine-2-carboxamides. 7 compounds $(4,5,8,10,15,17$, 18) have the $\mathrm{IC}_{50}$ values less than $10 \mu \mathrm{M}$.

The complexes of the most active compounds with the ATP-acceptor site of FGFR1 are shown in Fig. 1. The compounds possess typical binding modes of the type I protein kinases inhibitors. All compounds form hydrogen bond with the amino acid residues of the hinge region (Ala564). Compounds 5 and $\mathbf{8}$ (Fig. 3, a and b) form additional hydrogen bond with Asp641 in phosphate-binding pocket. The main feature of binding modes of all compounds is a large number of hydrophobic interactions with the amino acid residues of the ATP-binding site such as Leu630, Ile545, val561, Val492, Leu484, Ala512, Tyr563.

\section{Conclusions}

A series of FGFR1 inhibitors (18 compounds) was found using the receptor based virtual

Table 1. Structure and $\mathbf{I C}_{\mathbf{5 0}}$ of studied compounds.

\begin{tabular}{|c|c|c|c|c|c|c|c|c|c|c|c|}
\hline : & Structure & $\begin{array}{c}\mathrm{IC}_{50} \\
\mu \mathrm{M}\end{array}$ & $\begin{array}{c}\text { Yield, } \\
\% \\
\end{array}$ & : & Structure & $\begin{array}{c}\mathrm{IC}_{50} \\
\mu \mathrm{M}\end{array}$ & $\begin{array}{c}\text { Yield, } \\
\%\end{array}$ & : & Structure & $\begin{array}{c}\mathrm{IC}_{50} \\
\mu \mathrm{M}\end{array}$ & $\begin{array}{c}\text { Yield, } \\
\%\end{array}$ \\
\hline 1 & & 22.4 & 55 & 2 & & 40.5 & 52 & 3 & & 25 & 78 \\
\hline 4 & & 5.7 & 65 & 5 & & 3.8 & 67 & 6 & & 19.5 & 46 \\
\hline 7 & & 15.4 & 49 & 8 & & 8.9 & 88 & 9 & & 49 & 46 \\
\hline 10 & & 3.3 & 78 & 11 & & $>60$ & 72 & 12 & & 56.2 & 72 \\
\hline 13 & & 71 & 63 & 14 & & $>60$ & 59 & 15 & & 9.7 & 58 \\
\hline 16 & & 15 & 59 & 17 & & 7.9 & 72 & 18 & & 1.8 & 67 \\
\hline
\end{tabular}


$\boldsymbol{A}$

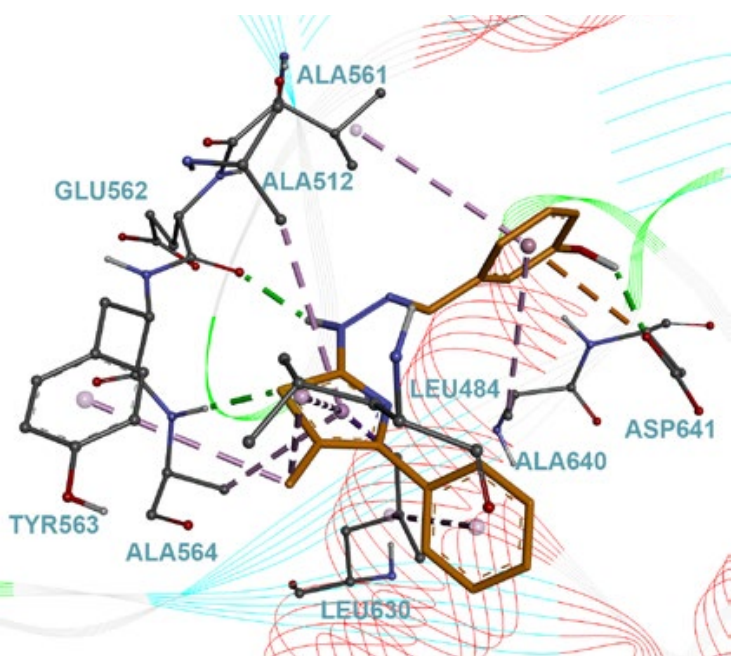

C

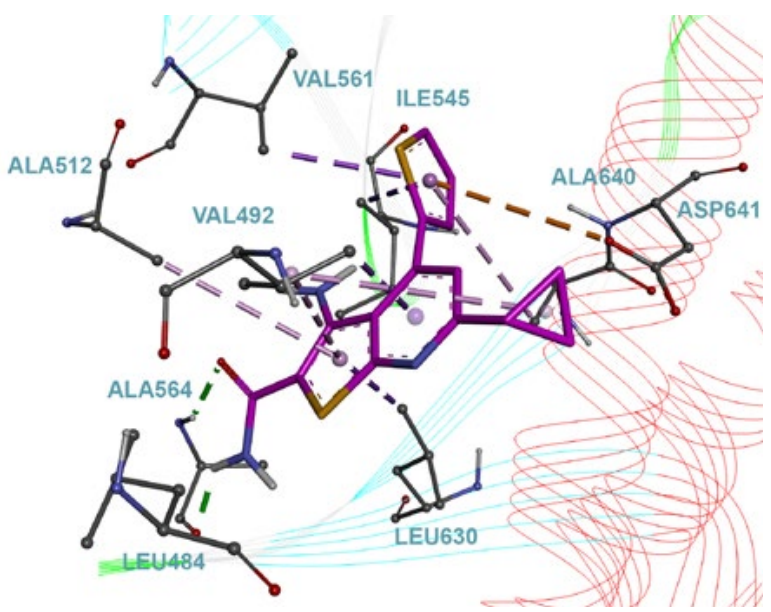

B

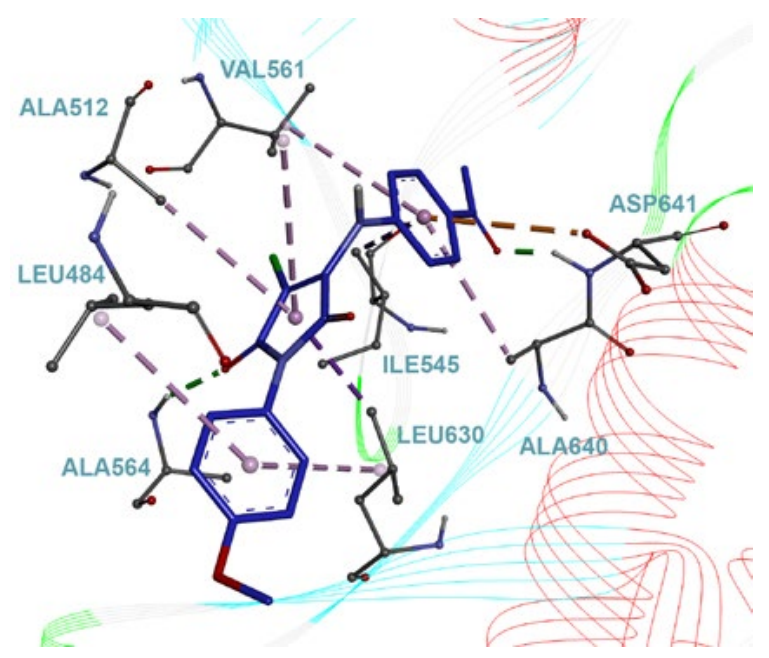

Fig. 1. The complexes of compounds 5 (a), 8 (b) and $\mathbf{1 8}$ (c) with ATP-acceptor site of FGFR1 obtained with Autodock 4.2.6. H-bonds are shown by green dashed lines, hydrophobic interactions - purple dashed lines.

screening of the 150,000 small-organic compounds library. $\mathrm{IC}_{50}$ values of studied inhibitors were in the range from 1.8 to $71 \mu \mathrm{M}$. These 18 compounds belong to 3 classes and are good candidates for the further development of effective FGFR1 inhibitors and potential anti-cancer drugs.

\section{Funding}

This work was supported by a grant from the National Academy of Sciences of Ukraine № 0117 U000204.

\section{REFERENCES}

1. Itoh $N$, Terachi T, Ohta M, Seo MK. The complete amino acid sequence of the shorter form of human basic fibroblast growth factor receptor deduced from its cDNA. Biochem Biophys Res Commun. 1990;169(2):680-5.

2. Weiss J, Sos ML, Seidel D, Peifer M, Zander T, Heuckmann JM, Ullrich RT, Menon R, Maier S, Soltermann A, Moch H, Wagener P, Fischer F, Heynck S, Koker M, Schöttle J, Leenders F, Gabler F, Dabow I, Querings S, Heukamp LC, BalkeWant H, Ansén S, Rauh D, Baessmann I, Altmüller J, Wainer Z, Conron M, Wright G, Russell P, Solo- 
mon B, Brambilla E, Brambilla C, Lorimier P, Sollberg $S$, Brustugun OT, Engel-Riedel W, Ludwig C, Petersen I, Sänger J, Clement J, Groen H, Timens W, Sietsma H, Thunnissen E, Smit E, Heideman D, Cappuzzo F, Ligorio C, Damiani S, Hallek M, Beroukhim R, Pao W, Klebl B, Baumann M, Buettner R, Ernestus K, Stoelben E, Wolf J, Nürnberg P, Perner $S$, Thomas RK. Frequent and focal FGFR1 amplification associates with therapeutically tractable FGFR1 dependency in squamous cell lung cancer. Sci Transl Med. 2010;2(62):62ra93.

3. Wu J, Wei T, Tang $Q$, Weng $B, L i W$, Jiang $X$, Ding $T$, Li X, Liang G, Cai Y, Ji J. Discovery and anticancer evaluation of two novel non-ATP-competitive FGFR1 inhibitors in non-small-cell lung cancer. BMC Cancer. 2015;15:276.

4. Irschick R, Trost T, Karp G, Hausott B, Auer M, Claus P, Klimaschewski L. Sorting of the FGF receptor 1 in a human glioma cell line. Histochem Cell Biol. 2013;139(1):135-48.

5. Turner N, Pearson A, Sharpe R, Lambros M, Geyer $F$, Lopez-Garcia MA, Natrajan $R$, Marchio $C$, Iorns E, Mackay A, Gillett C, Grigoriadis A, Tutt A, Reis-Filho JS, Ashworth A. FGFR1 amplification drives endocrine therapy resistance and is a therapeutic target in breast cancer. Cancer Res. 2010;70(5):2085-94.

6. Yang F, Zhang Y, Ressler SJ, Ittmann MM, Ayala GE, Dang TD, Wang F, Rowley DR. FGFR1 is essential for prostate cancer progression and metastasis. Cancer Res. 2013;73(12):3716-24.

7. Zhang Y, Guo KJ, Shang H, Wang YJ, Sun LG. Expression of aFGF, bFGF, and FGFR1 in ovarian epithelial neoplasm. Chin Med J (Engl). 2004;117(4):601-3.

8. Gryshchenko AA, Levchenko $K V$, Bdzhola VG, Ruban TP, Lukash LL, Yarmoluk SM. Design, synthesis and biological evaluation of naphthostyril derivatives as novel protein kinase FGFR1 inhibitors. $J$ Enzyme Inhib Med Chem. 2015;30(1):126-32.

9. Gryshchenko AA, Bdzhola VG, Balanda AO, Briukhovetska NV, Kotey IM, Golub AG, Ruban TP, Lukash LL, Yarmoluk SM. Design, synthesis and biological evaluation of N-phenylthieno[2,3-d]pyrimidin-4-amines as inhibitors of FGFR1. Bioorg Med Chem. 2015;23(9):2287-93.
10. Gryshchenko AA, Bdzhola VG, Pletnyova LV, Chepurna RV, Zhitnetsky IV, Yarmoluk SM. Quinazolone inhibitors of protein kinase FGFR1. Ukr Bioorg Acta. 2010; 8(2):63-8.

11. Gryshchenko AA, Bdzhola VG, Borovikov OV, Kukharenko OP, Pletnyova LV, Yarmoluk SM. Search for FGFR1 inhibitors among oxindole derivatives. Ukr BioorgActa; 2009; 7(2):64-8.

12. Gryshchenko AA, Tarnavskiy SS, Levchenko KV, Bdzhola VG, Volynets GP, Golub AG, Ruban TP, Vygranenko KV, Lukash LL, Yarmoluk SM. Design, synthesis and biological evaluation of 5-amino4-(1H-benzoimidazol-2-yl)-phenyl-1,2-dihydropyrrol-3-ones as inhibitors of protein kinase FGFR1. Bioorg Med Chem. 2016;24(9):2053-9.

13. Grischenko AA, Bdzhola VG, Kukharenko OP, Yarmoluk SM. Search for FGFR1 inhibitors among chromone derivatives. Ukr Bioorg Acta. 2009; 7(1):50-6.

14. Morris GM, Huey $R$, Lindstrom $W$, Sanner MF, Belew RK, Goodsell DS, Olson AJ. AutoDock4 and AutoDockTools4: Automated docking with selective receptor flexibility. J Comput Chem. 2009;30(16): 2785-91.

15. Pedretti A, Villa L, Vistoli G. VEGA--an open platform to develop chemo-bio-informatics applications, using plug-in architecture and script programming. J Comput Aided Mol Des. 2004;18(3):167-73.

16. Syniugin AR, Ostrynska OV, Chekanov MO, Volynets GP, Starosyla SA, Bdzhola VG, Yarmoluk SM. Design, synthesis and evaluation of 3-quinoline carboxylic acids as new inhibitors of protein kinase CK2. J Enzyme Inhib Med Chem. 2016;31(sup4):160 169.

17. Mukherjee H, Debreczeni J, Breed J, Tentarelli S, Aquila B, Dowling JE, Whitty A, Grimster NP. A study of the reactivity of S((VI))-F containing warheads with nucleophilic amino-acid side chains under physiological conditions. Org Biomol Chem. 2017;15(45):9685-9695.

18. Beyer H, Schindler W, Leverenz K. Über Thiazole, XXXVII. Chinoide Azomethinfarbstoffe aus Thiazolyl-(2)-hydrazin-Derivaten. Chemische Berichte. 1958;91(11):2438-45.

19. Hassan KhM, Kamal El-Dean AM, Youssef MSK, Atta FM, Abbady MS. Synthesis and reactions of 
some thienopyridine derivatives. II Phosphorus, Sulfur Silicon Relat Elem. 1990;47(1-2):181-9.

20. Wagner G, Vieweg H, Leistner, Boehm SN, Krasselt U, Hanfeld V, Prantz J, Grupe R. ChemInform abstract: synthesis of new primary, secondary, and tertiary 3-Aminothieno(2,3-b)pyridine-2-carboxamides on different ways. ChemInform. 1990;21(35):102-9.

21. Shestopalov AM, Promonenkov VK, Sharanin YuA, et al. Cyclization of nitriles. Syntheses and reactions of 3-amino-2-carboxamide-thieno[2,3-b]pyridines. J Org Chem USSR. 1984;20(7):1382

22. Byrd CM, Dai Dongchen, Jordan Robert. Hruby Dennis. Thienepiridines derivatives for the treatment and prevention of dengue virus infections. WO2010/99166, 2010, A1.

23. Tarnavsky SS, Dubinina GG, Yarmoluk SM, Golovach $S M$. Interaction 3,4-dichloromaleimides with $\mathrm{N}$ - and S-nucleofiles. Ukr Khim Zh. 2002;68(9):47-51.

24. Tarnavsky SS, Dubinina GG, Golovach SM, Yarmoluk SM. Antitumor activity among derivatives of the 3-chloro-4-(3-hydroxyanilino) -2,5-dihydropyrrole-2,5-dione. Biopolym Cell. 2003;19(6):548-52.

Ідентифікація сполук-хітів - інгібіторів FGFR1 методом рецепторно-оріснтовного віртуального скринінгу

С. С. Тарнавський, М. В. Протопопов,

О. В. Боровіков, А. О. Приходько, В. Г. Бджола, С. М. Ярмолюк, В. І. Матюшок, А. О. Баланда

Мета. Пошук нових інгібіторів протеїнкінази FGFR1. Методи. Віртуальний скринінг бібліотеки низькомолекулярних сполук проводили методом молекулярного докінгу 3 використанням програмного пакету Autodock 4.2.6. Активність інгібіторів визначали у біохімічних тестах in vitro із використанням $\gamma$-32Р АТФ. Результати. Експерименти in vitro показали, що 18 сполук проявляють інгібувальну активність щодо FGFR1 зі значенням $\mathrm{IC}_{50}$ в межах від 1,8 до $71 \mu \mathrm{M}$.
Активні сполуки належать до 3 хімічних класів. Висновки. За допомогою методів молекулярного моделювання та біохімічного тестування було знайдено низку інгібіторів FGFR1, що є перспективними для подальшої оптимізації з метою розробки більш активних інгібіторів цієї протеїнкінази.

К л ю ч о в і с л о в а: Протеїнкіназа FGFR1, молекулярний докінг, віртуальний скринінг, in vitro тестування.

\section{Идентификация хит-соединений - ингибиторов FGFR1 методом рецепторно-ориентированного виртуального скрининга.}

С. С. Тарнавский, Н. В. Протопопов,

А. В. Боровиков, А. А. Приходько, В. Г. Бджола, С. М. Ярмолюк, В. И. Матюшок, А. А. Баланда

Цель. Поиск новых химических соединений со способностью ингибировать протеинкиназу FGFR1. Методы. Виртуальный скрининг библиотеки низкомолекулярных органических соединений осуществляли при помощи метода молекулярного докинга программным пакетом Autodock 4.2.6. Активность ингибиторов изучали при помощи биохимических тестов in vitro, используя $\gamma_{-32}{ }^{32}$ АТФ. Результаты. Биохимическое тестирование показало, что 18 соединений ингибируют протеинкиназу FGFR1 в диапазоне значений $\mathrm{IC}_{50}$ от 1.8 до $71 \mu \mathrm{M}$. Активные соединения являются производными от 3 химических классов. Выводы. Используя методы молекулярного моделирования и биохимического тестирования было обнаружено ряд ингибиторов FGFR1, которые являются перспективными для последующей оптимизации с целью разработки более активных ингибиторов исследуемой протеинкиназы.

К л юч е в ы е с л о в а: Протеинкиназа FGFR1, молекулярный докинг, виртуальный скрининг, in vitro тестирование.

Received 02.11.2018 